\title{
MERANCANG BUKU STIPPLING DENGAN GAYA ILUTSRASI TITIK HITAM DAN PUTIH
}

\author{
Adi Nuryono, Azhari Amri \\ Program Studi Desain Komunikasi Visual \\ Fakultas Bahasa dan Seni, Universitas Indraprasta PGRI
}

\begin{abstract}
Abstrak. Stippling lebih akrab dengan sebutan Pointilisme, jika pointilisme menggunakan pencampuran warna primer atau warna-warna cerah, stippling hanya menggunakan warna hitam dan putih. Stippling merupakan teknik gambar yang membentuk shading teratur dan bertahap untuk menciptakan suatu ilusi optik yang sangat benar dan nyata. Persepsi umum inilah yang menjadi tujuan penulis untuk kembali menempatkan teknik dan gaya stipling sesuai sebutan istilahnya. Teknik lukis Stippling ini dapat melatih kesabaran dan mampu mengontrol emosi seorang desainer grafis. Teknik lukis stippling juga memberikan kesan berbeda yaitu dengan cara di titik dan membaca gelap terang atau cahaya dalam pembuatannya, hal ini tentu berbeda dengan teknik proses menggambar pada umumnya, yang hanya menggunakan goresan, coretan, maupun sapuan kuas. Penyamaan Istilah Pointilisme sama dengan Stippling, tidak jarang terjadi di tingkat pelajar/mahasiswa bahkan praktisi hingga akademisi. Dengan menggunakan metode perancangan, penulis akan merancang buku gaya ilustrasi teknik wana hitam dan putih atau Stippling. Dengan hasil perancangan ini, setidaknya penulis mencoba mengembalikan istilah Stippling sesuai dengan proses teknik perancangannya.
\end{abstract}

Keywords: Stippling, Pointilisme, Ilustrasi, Desain.

\begin{abstract}
Abstrak. Stippling which better known as Pointillism, uses only black and white when Pointillism using primary colors or bright colors. Stippling is a drawing technique that makes ordered and gradual shading to create optical illusions that look very real. This general perception is the goal to re-place the techniques and styles that match the term. This Stippling painting technique can practice patience and be able to controls the emotion of a graphic designer. The stippling painting technique also gives certain impressions which is difference in the way of making some points and how highlight and shadow are made, this is certainly different from the general drawing process technique which only uses brushes and strokes. The equation of the term Pointillism is the same as Stippling frequently occurs among students to practisioners and even academics. Using a design method, the author designs a book using Stipping style with black and white. Through the results, the author tries to bring back the term of Stippling in accordance with the design process.
\end{abstract}

Keywords: Stippling, Pointilism, Illustration, Design.

Correspondence author: Adi Nuryono, adi.mbasund@gmail.com, Depok, Indonesia

This work is licensed under a CC-BY-NC 


\section{Pendahuluan}

Kegiatan seni dilakukan manusia melalui perasaannya, yaitu rasa indah yang menghasilkan karya estetis dan memiliki makna simbolik. Di dalam berkesenian terdapat bermacam cara dan gaya dalam melakukannya. Salah satunya dapat dilakukan dengan seni rupa dimana penerapannya berbentuk dua dimensi atau tiga dimensi karena memiliki panjang dan lebar, serta volume yang mampu mengungkapan gagasan dan perasaan manusia yang diwujudkan melalui pengolahan media dan penataan elemen titik, garis, bidang, bentuk, volume, warna tekstur, dan pencahayaan dengan mengacu pada prinsip-prinsip desain.

Di Indonesia banyak sekali cara untuk mempublikasikan suatu benda atau bahan penting lainnya, namun kebanyakan hanya menggunakan foto dan kurang ada nilai estetis di lihat dari banyaknya seni yang ada saat ini. Ada juga dengan lukisan namun bahan, media lukis dan biaya pun masih menjadi kendala, contohnya dalam membeli peralatan lukis seperti kanvas dan cat. Keterbatasan seharusnya tidak menjadi penghalang untuk berkesenian, ada banyak cara yang dapat dibuat tidak harus dengan peralatan yang mahal dan mewah. Banyak teknik lukis yang di ajarkan satu diantaranya teknik stippling dimana medianya hanya menggunakan warna hitam dan putih dapat dilakukan hanya menggunakan kertas dan pena (bolpoin), teknik stippling adalah penggunaan titik-titik untuk menciptakan shading dan tekstur dalam lukisan dan gambar.

Stippling atau lebih akrab dengan sebutan Pointilisme dapat dibedakan dari warnanya, jika pointilisme menggunakan pencampuran warna primer atau warna-warna cerah berbeda dengan stippling yang hanya menggunakan warna hitam dan putih. Teknik stippling dapat dilakukan dengan Cat, krayon, conte, arang, pastel dan sikat. Namun pena atau pensil, adalah alat yang paling umum digunakan untuk stippling karena lebih mudah untuk mengontrol. Teknik lukis Stippling ini juga dapat melatih kesabaran dan mengontrol emosi. Teknik lukis stippling memberikan kesan yang beda yaitu dengan cara di titik dan membaca gelap terang atau cahaya dalam pembuatannya, berbeda dengan teknik-teknik proses menggambar pada umumnya yang hanya menggunakan goresan, coretan, maupun sapuan kuas. Kebanyakan media informasi yang ada hanya menggunakan photo untuk mewakili objek yang di kajinya. Oleh sebab itu dengan melihat permasalahan yang ada maka diperlukan adanya inisiatif tentang bagaimana menciptakan sebuah ilustrasi gambar atau bentuk expresi yang berbeda dalam melihat suatu objek.

Terlihat dari pernyataan tersebut terdapat adanya kekuatan dan kelemahan pada objek. Melalui landasan itulah, peneliti perlu rasanya membuat rancangan desain buku Teknik Stippling sebagai salah satu dari sebagian teknik yang masih jarang didengar, terkait belum adanya buku yang membahas tentang teknik Stippling. Buku Teknik Stippling ini yang nantinya akan memberi gambaran dalam proses membuat lukisan Stippling dan contoh karya agar dapat menarik minat masyarakat, hal ini dibatasi mulai dari media, bidang, bentuk bagun dasar tiga dimensi, tumbuhan, hewan, efek, landscape, realita dan wajah dari sudut pandang peneliti.

\section{Metode Penelitian}

Penelitian ini menggunakan metode penelitian kualitatif, dengan sudut pandang interpretasi dalam mencapai tujuan penelitian yaitu perancangan karya desain buku stippling dengan teknik ilustrasi titik hitam dan putih. Penjelasan lebih lanjut diterangkan oleh Levi Strauss (1966), Kualitatif adalah penelitian dalam dirinya sendiri. Peneliti adalah bricolor, manusia serba bisa atau seorang pribadi yang mandiri dan profesional. Secara metaforis disebutkan sebagai 
manusia yang dapat menghasilkan segala sesuatu dengan apa yang ada di tangan. Hasilnya adalah bricolage, suatu analisis yang kompleks, reflektif, padat, mirip kliping, yang secara keseluruhan mewakili interpretasi penelitian penuh makna, (Levi Strauss dalam Ratna 97). Tahapan penelitian ini dimulai dengan meninjau hasil penelitian sebelumnya baik tentang pembahasan stippling dan pointilisme, kemudian peneliti meninjau salah satu karya desain stippling dan pointilisme sebagai referensi penciptaan. Tahap terakhir adalah proses perancangan yang memuat hasil karya ilustrasi dengan teknik stippling berwarna hitam dan putih.

\section{Pembahasan}

Pengertian Stippling adalah penggunaan titik-titik untuk menciptakan shading dan tekstur dalam lukisan dan gambar (Angiel 3). Bentuk shading yang teratur dan bertahap dapat menciptakan ilusi optic yang sangat benar dan nyata. Semakin dekat titik-titik, semakin gelap juga shading yang didapat. Untuk membuat tampilan shading yang bagus harus dilakukan dengan bertahap seperti mengontrol jarak antara titik-titik agar kedalaman gambar lebih dapat terlihat.

Sedangkan pengertian untuk llustrasi gambar adalah gambaran singkat alur cerita suatu cerita guna lebih menjelaskan salah satu adegan" (Kusmiati et al. 46). Secara umum ilustrasi selalu dikaitkan dengan menjelaskan sebuah cerita. Gambar ilustrasi adalah gambar atau bentuk visual lain yang menyertai suatu teks, tujuan utama dari ilustrasi adalah memperjelas naskah atau tulisan dimana ilustrasi itu dikumpulkan (Ensiclopedia Americana 787). Untuk membuat suatu gambar, Ilustrasi langsung tidak selalu menyampaikan kesan yang tepat dan mungkin perlu untuk memakai sketsa atau simulasi. Haruslah berhati-hati jika ilustrasi mencakup angka, umur, tipe orang dan pakaian, (Natadjaja 165).

Gambar ilustrasi merupakan gambar yang sifatnya menerangkan atau visualisasi dari suatu uraian, baik berupa berita, cerita, karangan atau naskah. Gambar untuk membantu memperjelas isi buku, atau karangan. Gambar ilustrasi juga merupakan gambaran singkat alur cerita suatu cerita guna lebih menjelaskan salah satu adegan. Penelitian permainan tradisional dengan media gambar ilustrasi merupakan bentuk visual dari teks atau kalimat dengan tujuan memperjelas audience yang secara umum belum dapat membaca dengan lancar, maka gambar ilustrasi dapat menerangkan secara umum karakter atau keseluruhan informasi, (Jafar).

Jika dikaitkan dengan stippling, karya ilustrasi memiliki banyak sekali teknik dan beragam alternatif gaya, lebih khusus kepada stippling dan pointilisme, kemunculan ilustrasi tersebut tidak lepas dari bentuk dasar yang paling sederhana yaitu titik. Kelompok impresionis disebut Pointilisme (terutama Seurat dan Pissarro) memutuskan untuk mendasarkan lukisan mereka pada titik-titik berwarna kecil. Pengamat kemudian membangun gambar dengan mencampurkan titik-titik ini. Persepsi realitas, dengan demikian, konsep dibangun oleh pengamat yang merupakan sebuah jenis baru dari representasi gambar multi modal yang menghasilkan gambar yang dihasilkan computer dengan teknik dan representasi gambar yang telah termotivasi oleh persepsi visual manusia. Dan disebut sebagai gaya Simbolik gambar "Pointilisme" karena meyerupai gambar impresionis tertentu ditarik oleh sub-kelompok Pointilisme. Pointilisme dapat pula digunakan untuk menciptakan lukisan hitam putih, dengan menggunakan titik-titik, gambar dinamis dapat diciptakan, gaya teknik pointilisme ini biasa disebut teknik stippling. 
Tinjauan pustaka yang dicantumkan dalam penelitian ini lebih menitik beratkan kepada artikel ilmiah baik yang dipublikasikan maupun yang tidak dipublikasikan dalam jurnal ilmiah. Berikut ini adalah artikel ilmiah sebagai pustaka yang mendahului dari penelitian ini, di antaranya:

1. Oliver Deussen, Stefan Hiller and Thomas Strothotte. Yang berjudul "Floating Points: $A$ Method for Computing Stipple Drawings Structures". Volume 19, 2000 Number 3.

Menyebutkan bahwa membuat gambar dengan menggunakan sebagian besar titik-titik adalah kuat dan banyak digunakan metode ilustrasi. Biasanya, beberapa puluh ribuan titik diatur secara manual untuk menghasilkan satu gambar. Berbagai metode untuk menempatkan titik dan control- penekanan, jarak dan ukuran digunakan untuk mewakili bahan yang berbeda. Teknik ini disebut sebagai stippling. Manfaat artikel ini bagi peneliti yaitu adannya penjelasan tentang pembahasan teknik stippling dan metode pengerjaannya yang bisa dijadikan sebagai referensi dalam bahan pembuatan buku menggambar teknik stippling (Deussen et al.).

2. Cindy Angiel yang berjudul "Stippling with Layer - Three Style Tutorial" 2012/03/ Stippling Tutorial.

Menyebutkan bahwa stippling adalah teknik menggambar tinta di mana dengan menerapkan nada dan tekstur di titik-titik kecil. Dengan mengatur kedalaman nada dan kekasaran tekstur dengan memvariasikan kepadatan dan distribusi titik-titik. Kunci untuk nilai transisi dengan teknik ini adalah penempatan titik-titik di dekat dengan titik-titik lainnya. Dengan demikian, semakin kecil pena yang digunakan dalam sebuah karya stippling, maka semakin halus transisi nilai yang dapat dicapai. Jika dilakukan dengan cara yang masuk akal, sebuah pena yang baik juga dapat digunakan berdekatan dengan pena besar untuk secara efektif membuat berani atau tekstur dalam sebuah komposisi. Manfaat artikel ini bagi peneliti yaitu adannya penjelasan dan tahapan-tahapan terdiri dari tiga gaya proses menggambar dengan stippling (Angiel).

3. Oliver Deussen, Stefan Hiller, Cornelius van Overveld, Thomas Strothotte. Yang berjudul "Floating Points: A Method for Computing Stipple Drawings". Volume 19, 2000 Number 3. Menyebutkan bahwa poin biasanya didistribusikan secara acak tapi hampir merata spasi dimana pola titik yang teratur digunakan. Selama beberapa bahan, penempatan titik-titik yang memiliki arah utama, garis juga harus menggunakan titik-titik yang digabungkan agar membentuk garis dan ukuran titik dapat bervariasi untuk daerah yang lebih ringan dan lebih gelap. Sedangkan dibeberapa ilustrasi bentuk titik-titik individual bervariasi harus menggunakan pena dengan tegak lurus dan biasanya dalam membuat titik yang cepat dapat digunakan alat bantu kertas sebagai tatakan (Deussen et al.).

4. Witabora, Joneta. "Peran dan perkembangan Ilustrasi." Humaniora 3.2 (2012): 659-667. Penelitian ini menerapkan foto ke pensil dengan berkualitas tinggi, metode kontrol dicapai untuk menampilkan halus atas gaya gambar. Ini adalah tugas yang menantang karena beberapa jenis goresan (mis., garis besar dan naungan), kompleksitas struktural naungan pensil (mis., penetasan), dan kurangnya data pelatihan yang selaras berpasangan. Untuk mengatasi tantangan ini, kami mengembangkan model dua cabang yang mempelajari filter terpisah untuk menghasilkan garis-garis samar dan bayangan warna dari koleksi gambar pensil. Kami membuat pasangan data pelatihan dengan mengekstraksi membersihkan garis 
besar dan ilustrasi warna dari pensil asli gambar menggunakan teknik penyaringan gambar, dan kami secara manual beri label pada gaya gambar (Witabora).

5. Hartanto, Deddi Duto. "Penggunaan Ilustrasi sebagai daya tarik pada iklan media cetak." Nirmana 3.1 (2004).

Penggunaan ilustrasi pada iklan media cetak merupakan hal penting untuk diperhatikan. Ilustrasi bukan hanya sebagai hiasan yang menarik perhatian saja, tetapi sebagai visualisasi gagasan pesan iklan. Apabila tepat penggunaannya akan sangat efektif dalam menyampaikan isi pesan iklan tersebut (Hartanto).

6. Hagijanto, Andrian D. "Metode Dramatisasi llustrasi Pada Iklan Sebagai Wacana Budaya Kontemporer." Nirmana 4.1 (2004).

Ilustrasi dipakai sebagai elemen tak terpisahkan dalam iklan karena alasan daya tarik dapat mempengaruhi khalayak, dan dapat menyampaikan pesan secara akurat. Dramatisasi pada ilustrasi iklan merupakan hal yang biasa digunakan pada gaya pendekatan beriklan, sebagai bagian dari proses akselerasi pemahaman produk (Hagijanto).

Dari publikasi tersebut, dapat ditarik suatu kesimpulan bahwa untuk belajar menggambar tidaklah harus dengan coretan, goresan, maupun sapuan kuas. Melainkan dapat menggunakan penitikan dan tidak menggunakan bayak biaya dan media untuk melakukannya sehingga masyarakat dapat bereksplorasi dalam berkesenian khususnya dalam bidang menggambar teknik stippling.

Sedangkan dari hasil wawancara dengan narasumber yaitu Imam Bucah, seorang seniman dari kota Pati yang lahir pada 22 Mei 1970 memberikan informasi mengenai teknik ini dan menyebutnya dengan melukis bolpoin. Sebagai pelaku seni Imam Bucah menyatakan bahwa, Untuk mengatakan kapan aku melukis/mengambar degan bolpoin itu sulit, karena bolpoin sudah akrab di tangan sejak sekolah dulu. Mungkin lebih seneng menggambar dari pada mencatat pelajaran. Tapi itulah bolpoin tidak pernah menjadi materi serius untuk menggarap art. dari rasa ingin tahu dan tertantang untuk mengekploitasi bolpoin sampai di mana kekuatannya aku menceburkan diri mengasiki bolpoin sampai menjadi sebuah pameran tunggal dengan judul : INVASI BOLPOIN" tahun 2008. Bahwa bangsa ini atau pada umumnya seniman itu "miskin" maka harus mampu bekerja dengan material yang murah seperti bolpoin. Mencoba menghadirkan karya bolpoin yang bisa jadi menjadi artefak akir tentang kekuatan tangan manusia. Logikanya; dulu menulis itu membuat gerakan bersambung di atas sebuah bidang, tapi sekarang menulis itu pencet-pencet di tuts/tombol. Dengan ini lama-lama kekuatan drawing manusia akan semakin menurun dan bisa jadi akan musnah untuk kurun masa depan, (wawancara tanggal 25/12/2014).

Teknik stippling adalah salah satu dari sekian banyak teknik dalam menggambar, yang berbeda dengan teknik lainya, dan mempunyai cirri khas masing-masing. Teknik stippling sekarang ini jarang ada dan sangat terbatas dalam bentuk buku maupun proses dalam menggambar terlebih dengan bahasa Indonesia, kebanyakan buku teknik menggambar hanya dengan goresan, coretan, maupun sapuan kuas. Yang ada sekarang ini di toko-toko buku seperti gramedia hanya mengulas tentang teknik-teknik yang sudah banyak diketahui seperti realist, abstrak, namun jarang ada yang mengulas tentang teknik stippling.

Publikasi buku ilustrasi teknik Stippling dan Pointilisme terdapat pada Buku "Tallinn, VANALINNA GRAAFILISED VAATED" peneliti mendeskripsikan buku pada gambar cover buku ini terlihat "sebuah bangunan tua dengan menggunakan teknik stippling dan disertai dengan pengunaan warna cat air". VANALINNA GRAAFILISED VAATED" 


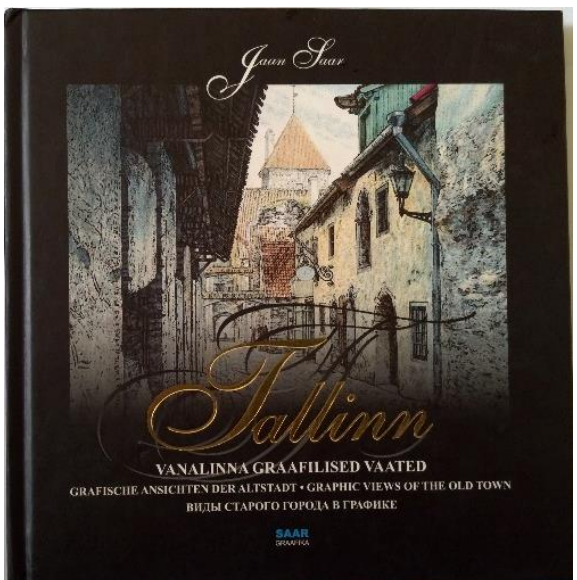

Gbr. 1 Cover Buku "Tallinn, VANALINNA GRAAFILISED VAATED"

(Sumber: Buku Koleksi Azhari Amri, Repro Scan Adi, 2014/11/4).

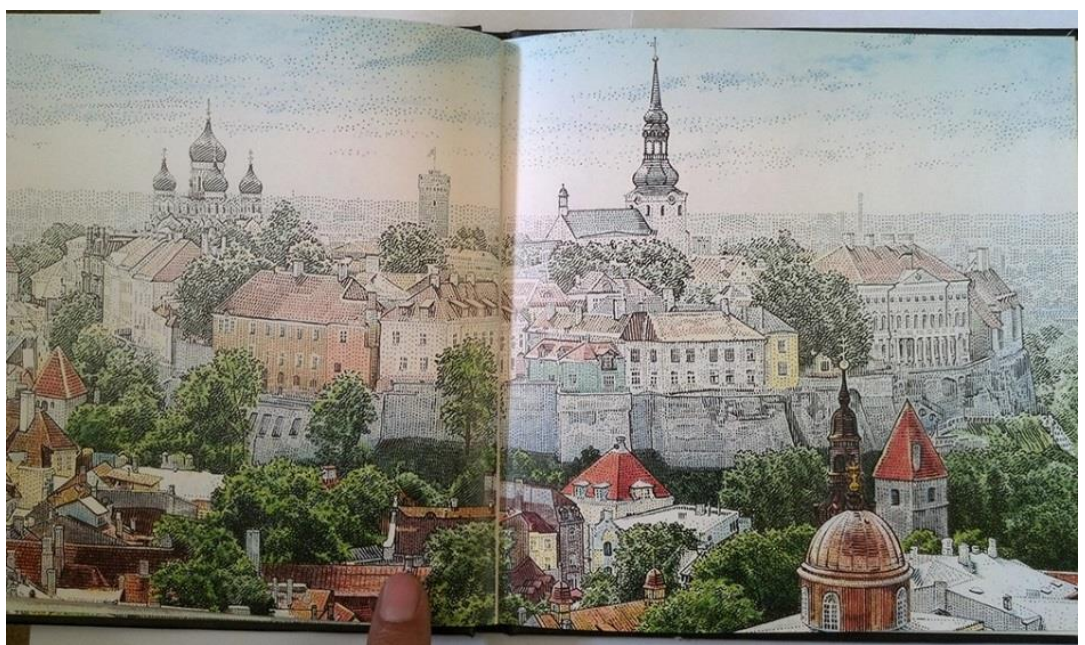

Gbr. 2 Isi Buku 3 "Tallinn, VANALINNA GRAAFILISED VAATED"

(Sumber: Buku Koleksi Azhari Amri, Repro Scan Adi, 2014/11/4).

Dengan ukuran buku $(10 \mathrm{~cm} \times 10 \mathrm{~cm})$ dan bahasa pada buku susah dimengerti sehingga sulit untuk memahaminya. Pada bagian isi buku menggunakan batuan cat air untuk menandai gelap terang suatu objek. Jadi dari kesimpulan dalam analisis diatas, perlu dibuatlah sebuah perancangan buku teknik stippling dengan didasari pada sebuah konsep dasar perancangan, yang secara teknik mengotimalkan peran teknik stippling dengan warna hitam dan putih.

Perancangan buku Stippling dengan gaya ilustrasi hitam dan putih dikhususkan pada target khalayak yaitu masyarakat Indonesia dengan rentang usia 17-28 tahun, dengan prilaku psikologis yang menyukai proses pembuatan karya seni dengan fokus wilayah penyebaran publikasi di Jakarta, Yogyakarta dan Bandung sebagai area dengan banyaknya komunitas seni lukis, desain grafis maupun komunitas menggambar.

Buku yang akan dibuat memiliki penjelasan proses awal pembuatan sketsa sampai proses penitikan pada bagian tertentu hingga menjadi gambar dengan teknik stippling, gambarnya mudah untuk di tiru dan dipelajari, menggunakan font yang mudah dibaca. Warna yang akan ditampilkan pada cover buku sesuai dengan makna atau simbol dari teknik stippling, yaitu warna hitam dan putih sesuai dengan ciri teknik stippling. Tanda visual yang akan 
ditampilkan pada cover buku nantinya akan menggunakan ikon teknik stippling itu sendir, dimaksudkan agar masyarakat dapat mengetahui dengan jelas ciri khas dari teknik stippling.

Metode ilustrasi yang digunakan adalah berupa olah kreatif teknik stippling, karena ingin menampilkan hasil gambar observasi berupa teknik stippling dengan melalui proses yang mudah dan dapat menarik minat masyarakat untuk mencobanya dan agar dapat terlihat menarik perhatian. Ilustrasi yang akan dijadikan sebagai desain sampul adalah ilustrasi si pengarang buku sendiri dengan hanya menampilkan setengah bagian muka. Ikon setengan muka dengan penggunaan teknik stippling digunakan pada cover buku agar dapat menarik perhatian dan rasa penasaran.

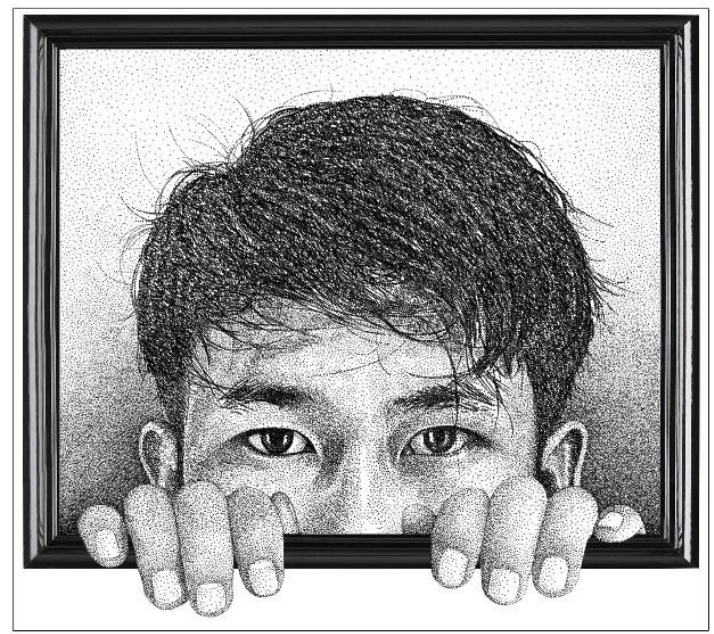

Gbr. 3 Teknik stippling dengan framing wajah penulis (Sumber: Dokumentasi Peneliti, 2015/1/15)

Sedangkan tata letak yang digunakan oleh peneliti dalam perancangan buku cara menggambar dengan teknik stippling ini yaitu menggunakan prinsip desain keseimbangan asimetris karena memberi kesan informal, tapi dapat terlihat lebih dinamis yang terbentuk dari perpaduan titik, bentuk, ukuran, maupun tata letak yang tidak sama namun tetap seimbang. dan penggunaan tata letak prinsip desain keseimbangan asismetris juga diaplikasikan pada beberapa media lainnya.

J $\quad$ U D D U L

GAMBAR

ILUSTRASI

Gbr. 4 Desain Layout (Tata Letak)

(Sumber: Dokumentasi Peneliti 2014/11/5). 
Tipografi yang digunakan pada cover buku adalah jenis Times New Roman. Society Editor Personal Use, dan Helvetica (OT1) Pemilihan tipografi ini dipilih oleh peneliti karena tipografi ini memiliki kesan karakter yang mudah dibaca, jelas, tidak rumit dan sudah sangat familiar sehingga sangat cocok untuk buku teknik stippling ini. karena pembuatan karyanya sudah sangat rumit, dari situlah peneliti ingin memberikan tipografi yang ringan dan mudah di pahami.

\section{Jenis : Helvetica (0T1) \\ Angka : 1234567890 \\ Tanda Baca : !@\#\$\%^\&*()_:"/k<> \\ Lowercase : abcdefghijklmnopqrstuvwxyz \\ Uppercase : ABCDEFGHIJKLIMNOPQRSTUVWXYZ}

Gbr. 5 Font Helvetica (OT1)

(Sumber: www.Dafont.com, diunduh 2015/1/5).

\begin{tabular}{|c|c|}
\hline Jenis & Society Editor Personal Use \\
\hline Angka & 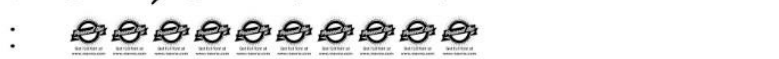 \\
\hline Tanda Baca & $: \quad \therefore @ 8 \% \& * 0 \ldots+: 10<<$ \\
\hline Lowercase & : abcdebghiphlmnopqusturwoxup \\
\hline Uppercase & : ABCDEFGAIDKL MNODQRSTUNXYZ \\
\hline
\end{tabular}

Gbr. 6 Font Society Editor Personal Use

(Sumber: www.Dafont.com, diunduh 2015/1/5).

\begin{tabular}{|c|c|}
\hline Jenis & Times New Roman \\
\hline Angka & : 1234567890 \\
\hline Tanda baca & : !@\#\$\%^\&*0_+:"?\{\}<> \\
\hline Lowercase & : abcdefghijklmnopqrstuvwxyz \\
\hline Uppercase & : ABCDEFGHIJKLMNOPGRSTUVWXYZ \\
\hline
\end{tabular}

Gbr. 7 Font Times New Romance

(Sumber: www.Dafont.com, diunduh 2014/11/5).

Dalam desain buku teknik stippling yang dibuat, peneliti tidak menggunakan bayak warna dan hanya menggunakan warna hitam karena warna ini menjadi ciri khas dari teknik stippling itu sendiri. Kalimat informatif dan persuasif yang digunakann peneliti pada Cover buku dan media pendukung lainnya adalah "Menggambar Teknik Stippling". Berikut karya teknik Stippling yang ada pada isi buku rancangan, 


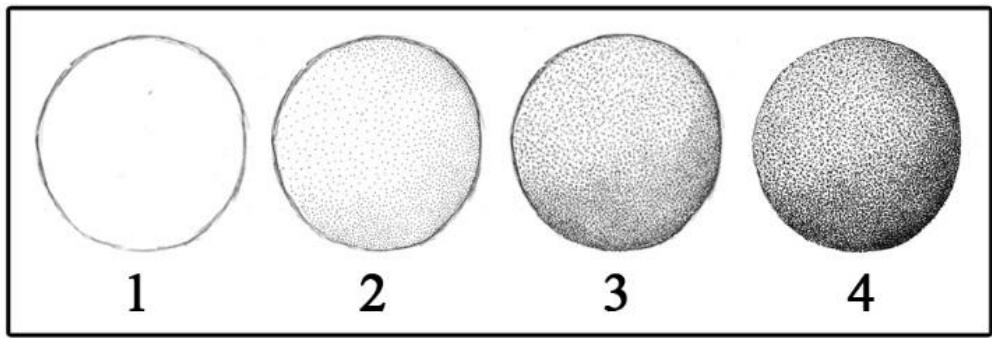

Gbr. 8 Proses Stippling dalam materi membuat Bentuk Bola (Sumber: Dokumentasi Peneliti, 2015/1/19).

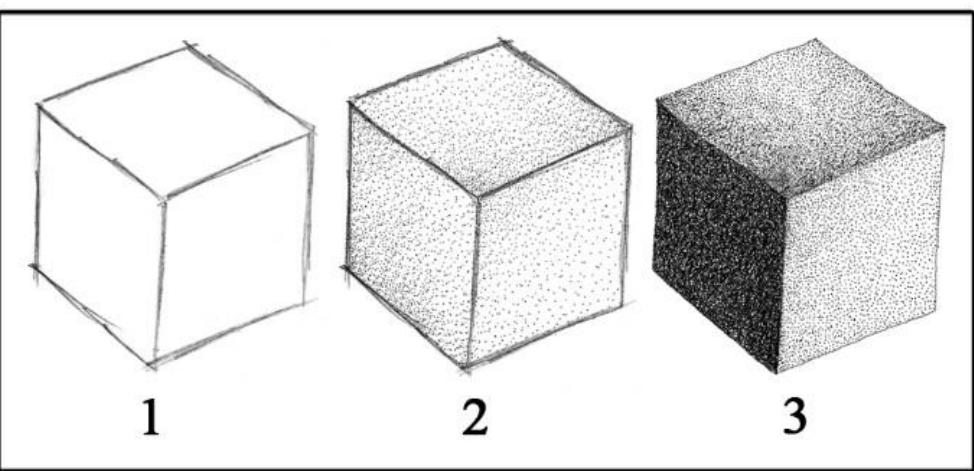

Gbr. 9 Proses Stippling dalam materi membuat Bentuk Kubus (Sumber: Dokumentasi Peneliti, 2015/1/19).

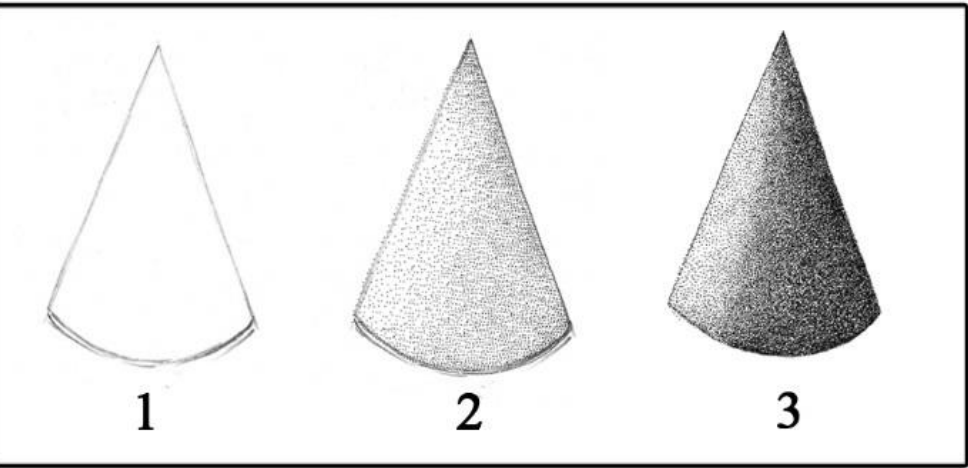

Gbr. 10 Proses Stippling dalam materi membuat Bentuk Kerucut (Sumber: Dokumentasi Peneliti, 2015/1/19).

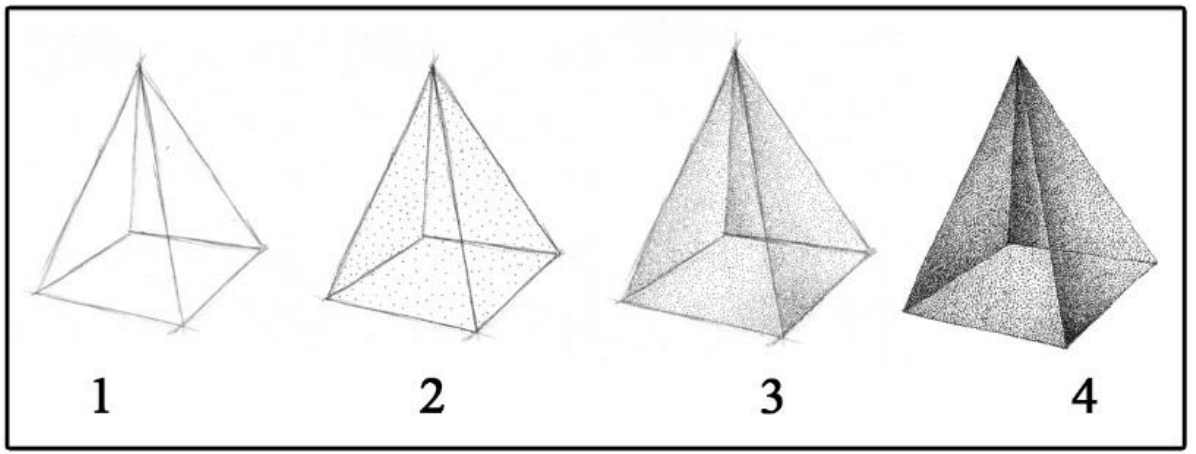

Gbr. 11 Proses Stippling dalam materi membuat Bentuk Prisma Bangun Ruang (Sumber: Dokumentasi Peneliti, 2015/1/19). 


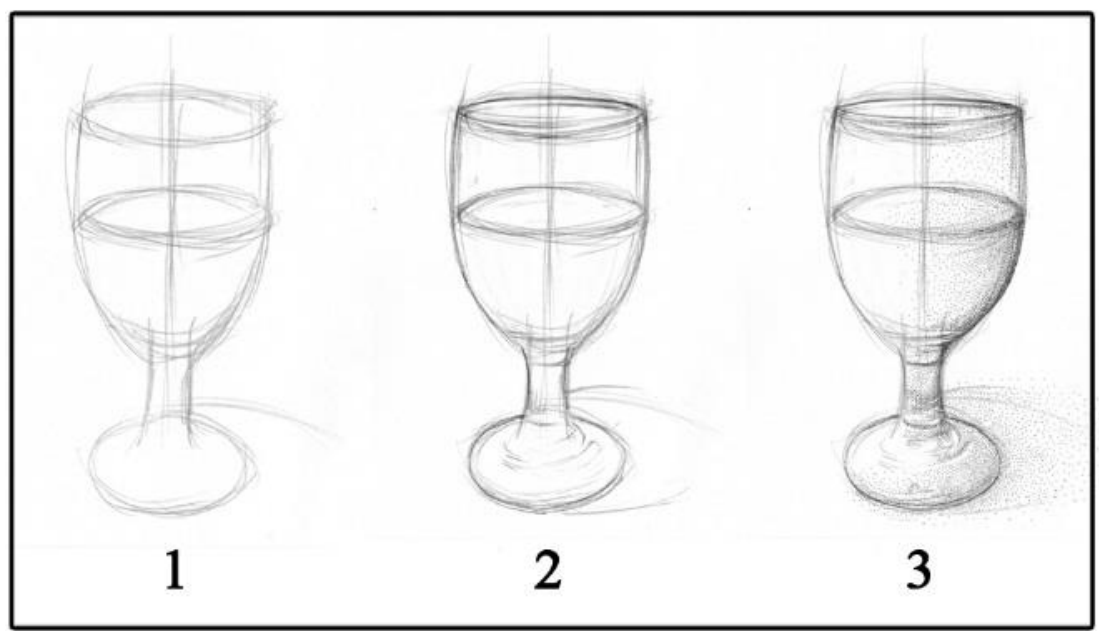

Gbr. 12 Proses Stippling dalam materi membuat Gelas tahap 1-3

(Sumber: Dokumentasi Peneliti, 2015/1/20).

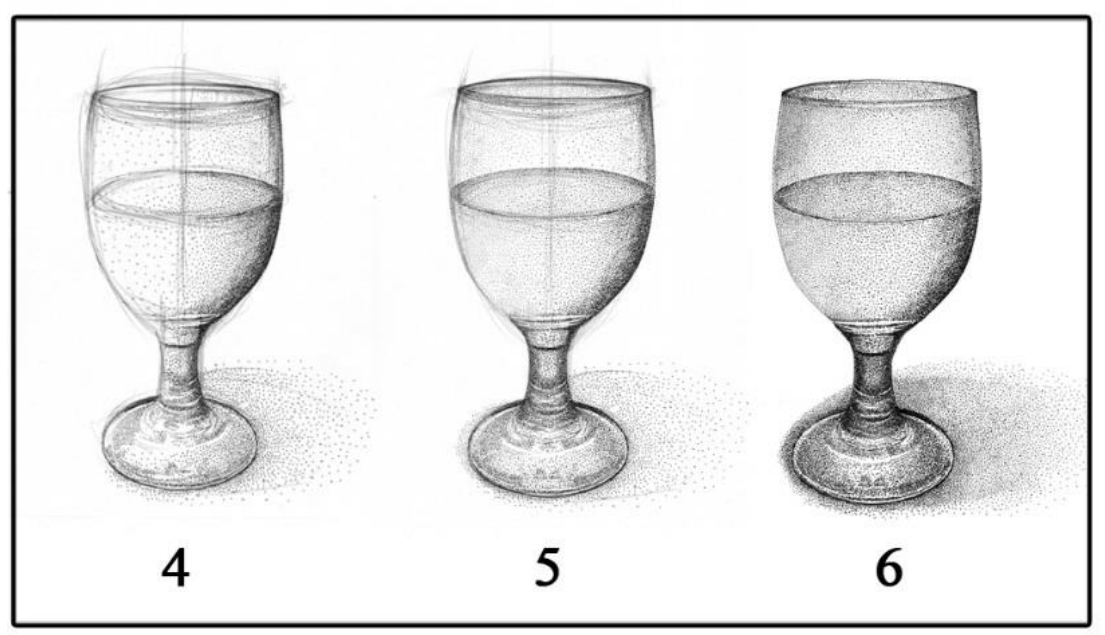

Gbr. 13 Proses Stippling dalam materi membuat Gelas tahap 4-6 (Sumber: Dokumentasi Peneliti, 2015/1/20).

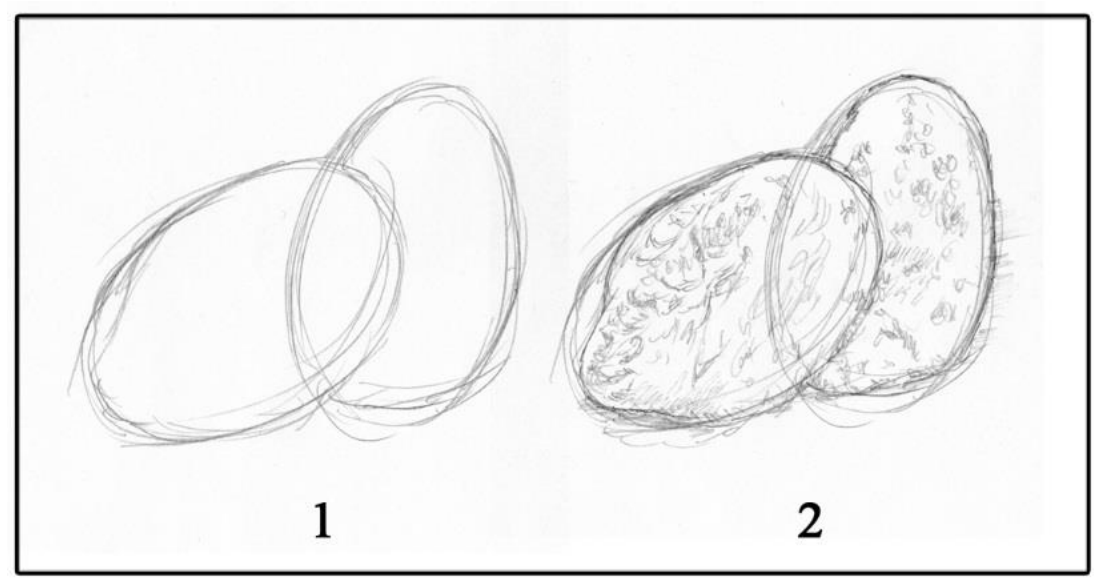

Gbr. 14 Proses Stippling dalam materi membuat Batu tahap 1-2

(Sumber: Dokumentasi Peneliti, 2015/1/20). 


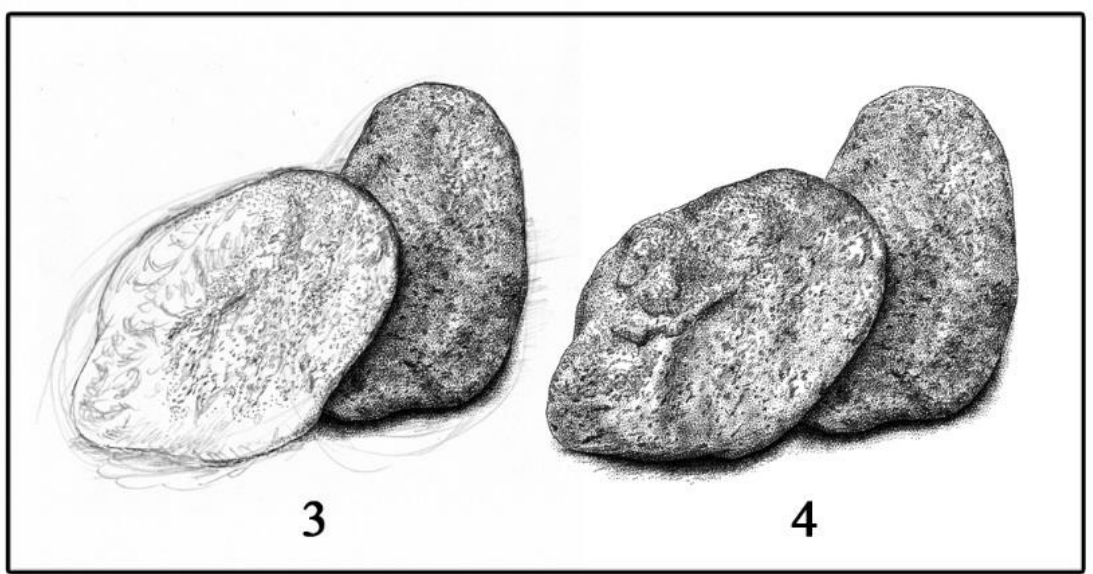

Gbr. 15 Proses Stippling dalam materi membuat Batu tahap 3-4 (Sumber: Dokumentasi Peneliti, 2015/1/20).

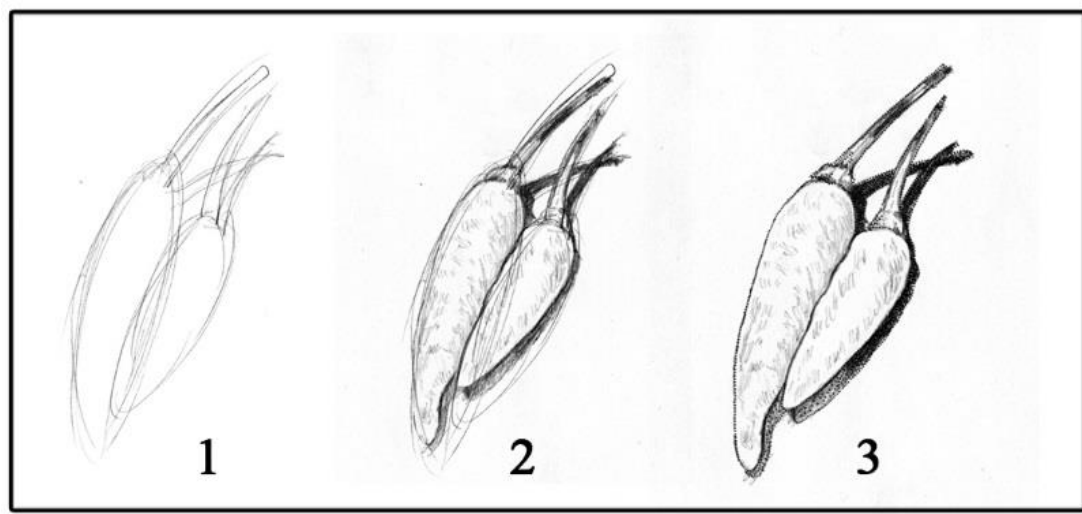

Gbr. 16 Proses Stippling dalam materi membuat Cabe Rawit tahap 1-3 (Sumber: Dokumentasi Peneliti, 2015/1/20)

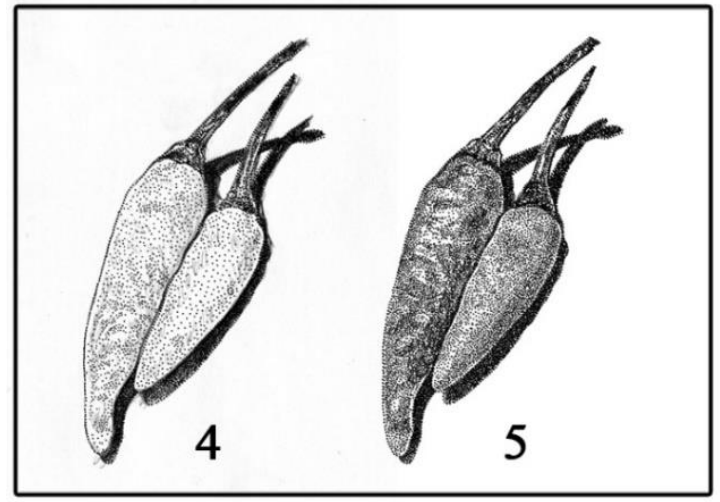

Gbr. 17 Proses Stippling dalam materi membuat Cabe Rawit tahap 4-5 (Sumber: Dokumentasi Peneliti, 2015/1/20). 


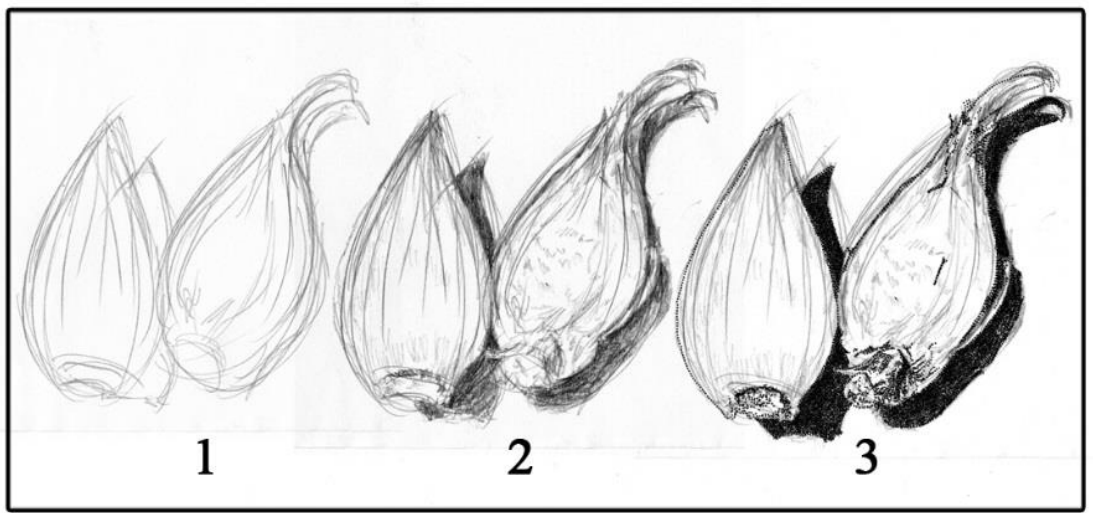

Gbr. 18 Proses Stippling dalam materi membuat Bawang Merah tahap 1-3 (Sumber: Dokumentasi Peneliti, 2015/1/21).

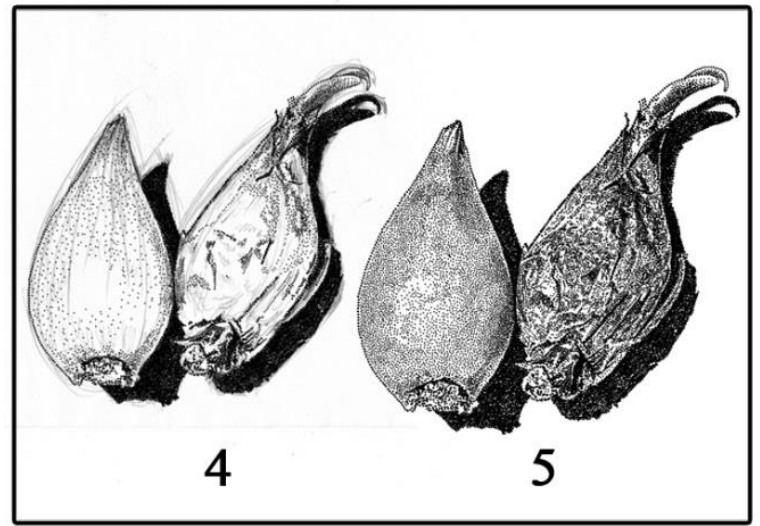

Gbr. 19 Proses Stippling dalam materi membuat Bawang Merah tahap 4-5 (Sumber: Dokumentasi Peneliti, 2015/1/21).

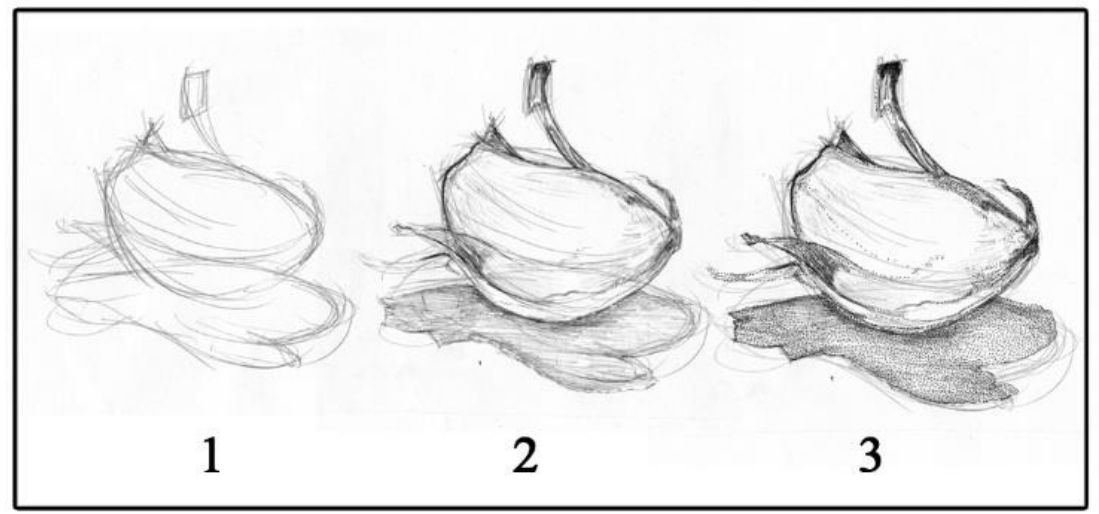

Gbr. 20 Proses Stippling dalam materi membuat Bawang Putih tahap 1-3 (Sumber: Dokumentasi Peneliti, 2015/1/21). 


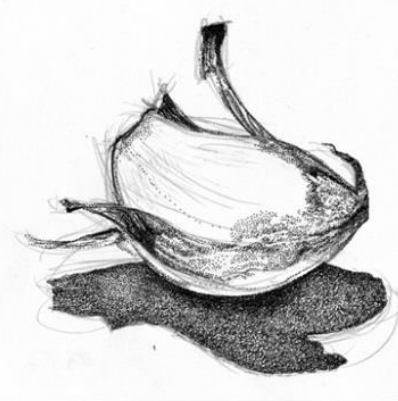

4

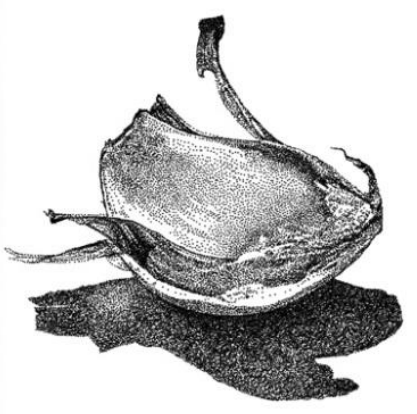

5

Gbr. 21 Proses Stippling dalam materi membuat Bawang Putih tahap 4-5 (Sumber: Dokumentasi Peneliti, 2015/1/21).

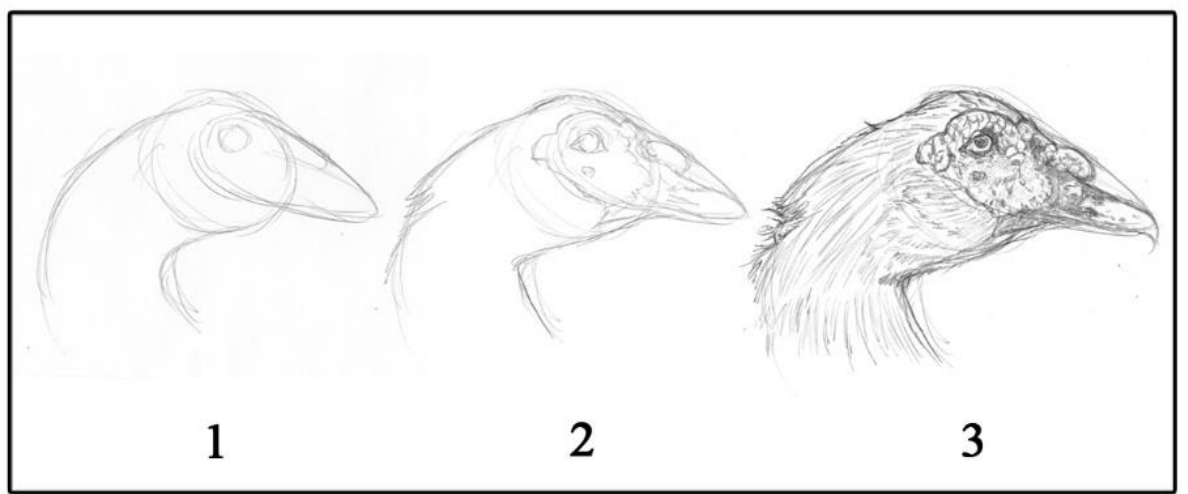

Gbr. 22 Proses Stippling dalam materi membuat Bebek tahap 1-3 (Sumber: Dokumentasi Peneliti, 2015/1/21).
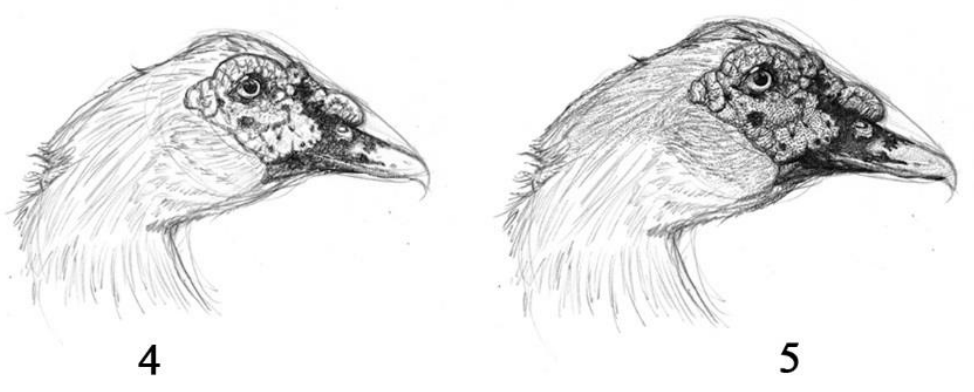

Gbr. 23 Proses Stippling dalam materi membuat Bebek tahap 4-5 (Sumber: Dokumentasi Peneliti, 2015/1/21). 


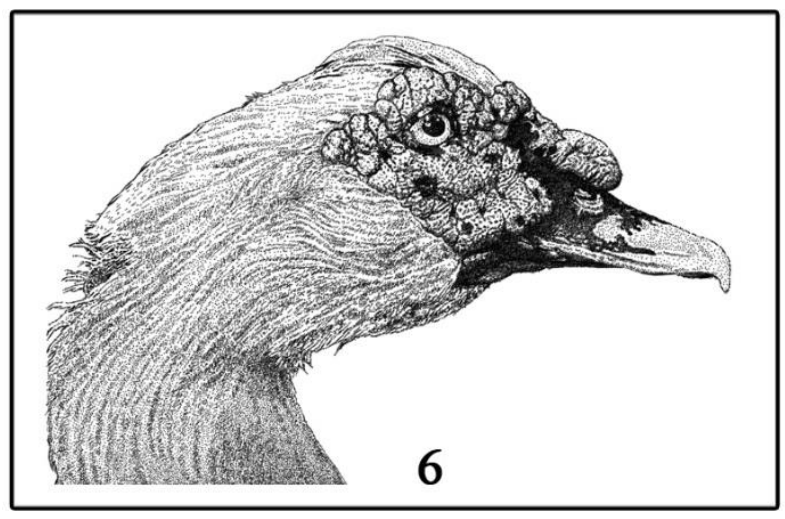

Gbr. 24 Proses Stippling dalam materi membuat Bebek tahap 6 (Sumber: Dokumentasi Peneliti, 2015/1/21).

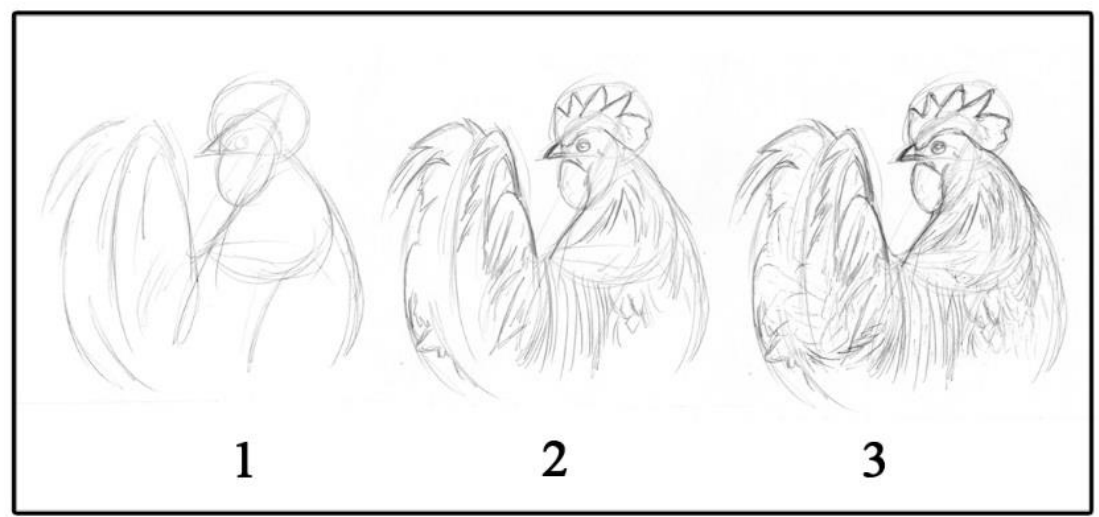

Gbr. 25 Proses Stippling dalam materi membuat Ayam tahap 1-3 (Sumber: Dokumentasi Peneliti, 2015/1/21).

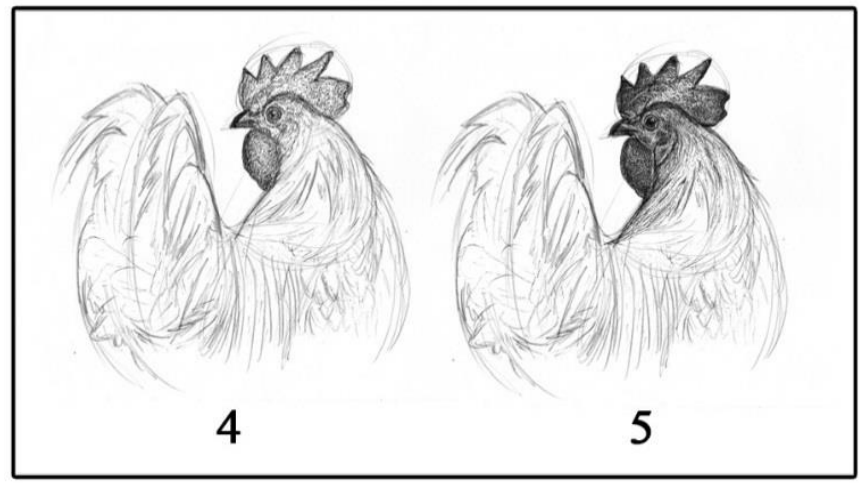

Gbr. 26 Proses Stippling dalam materi membuat Ayam tahap 4-5 (Sumber: Dokumentasi Peneliti, 2015/1/21). 


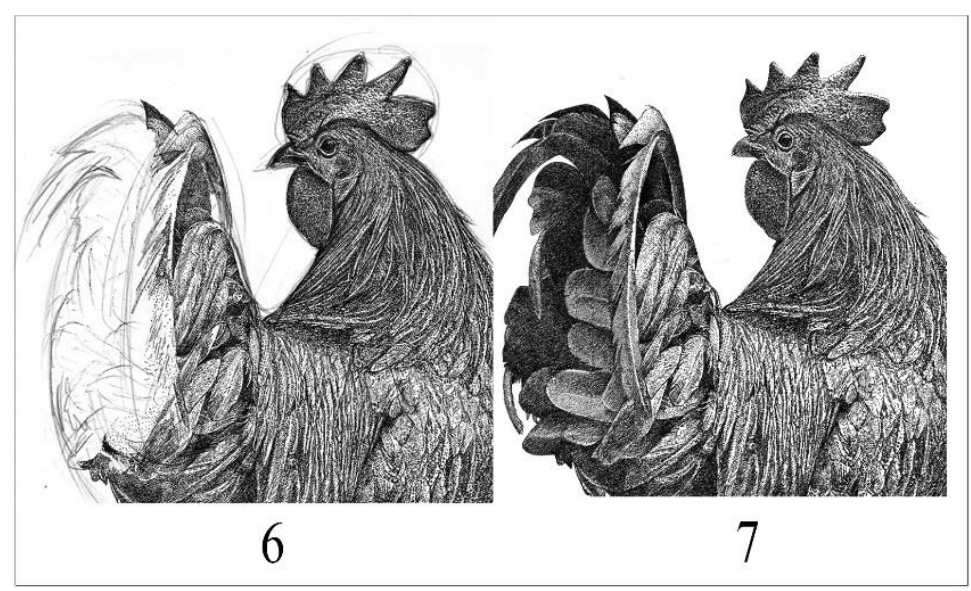

Gbr. 27 Proses Stippling dalam materi membuat Ayam tahap 6-7 (Sumber: Dokumentasi Peneliti, 2015/1/21).

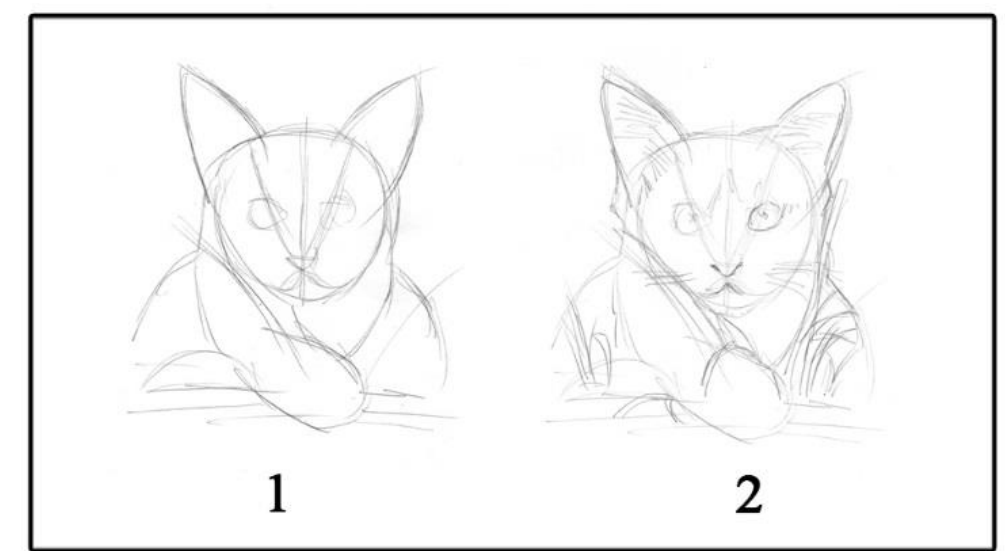

Gbr. 28 Proses Stippling dalam materi membuat Kucing tahap 1-2 (Sumber: Dokumentasi Peneliti, 2015/1/21).

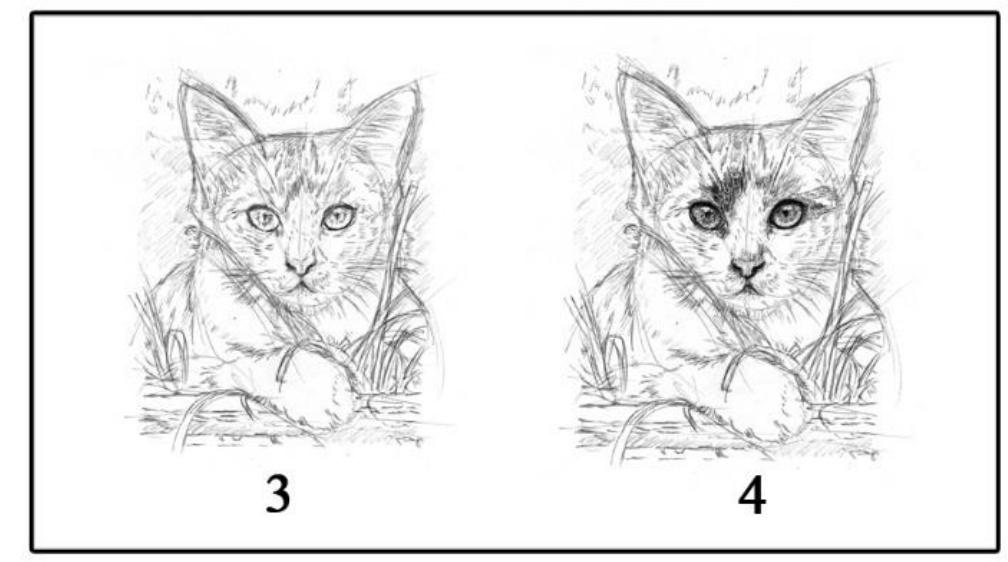

Gbr. 29 Proses Stippling dalam materi membuat Kucing tahap 3-4 (Sumber: Dokumentasi Peneliti, 2015/1/21). 
172 Merancang Buku Stippling dengan Gaya llustrasi Titik Hitam dan Putih Adi Nuryono dan Azhari Amri
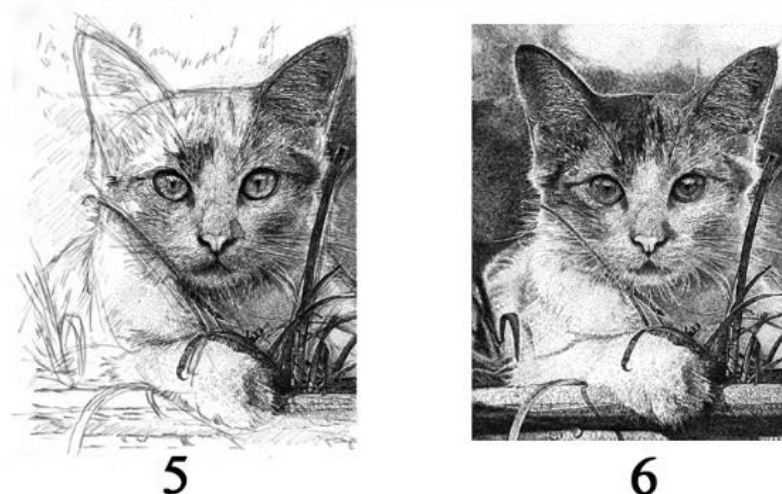

6

Gbr. 30 Proses Stippling dalam materi membuat Kucing tahap 5-6 (Sumber: Dokumentasi Peneliti, 2015/1/21).

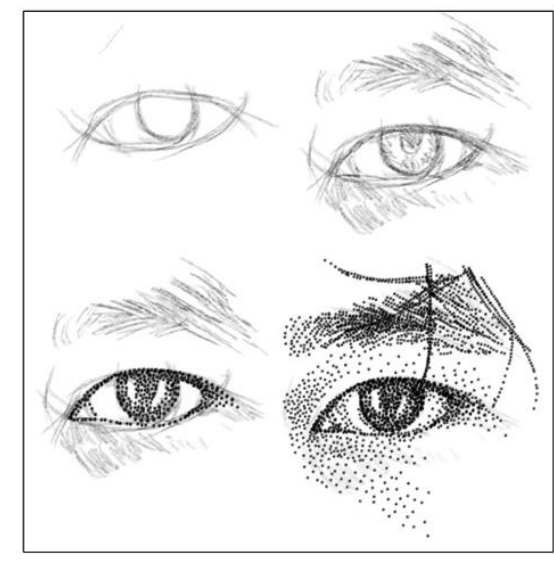

Gbr. 31 Proses Stippling dalam materi membuat Bagian Mata (Sumber: Dokumentasi Peneliti, 2015/2/5).

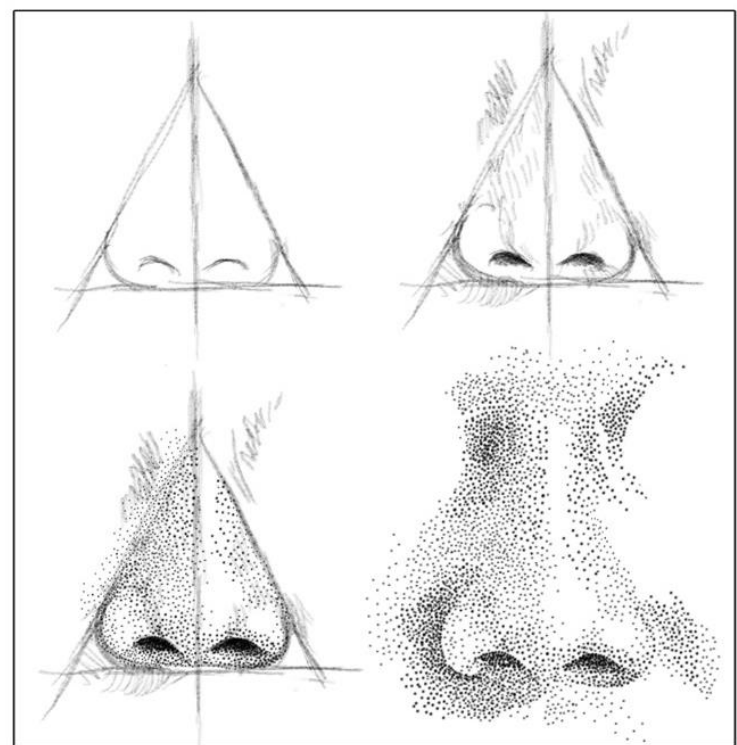

Gbr. 32 Proses Stippling dalam materi membuat Bagian Hidung (Sumber: Dokumentasi Peneliti, 2015/2/5). 


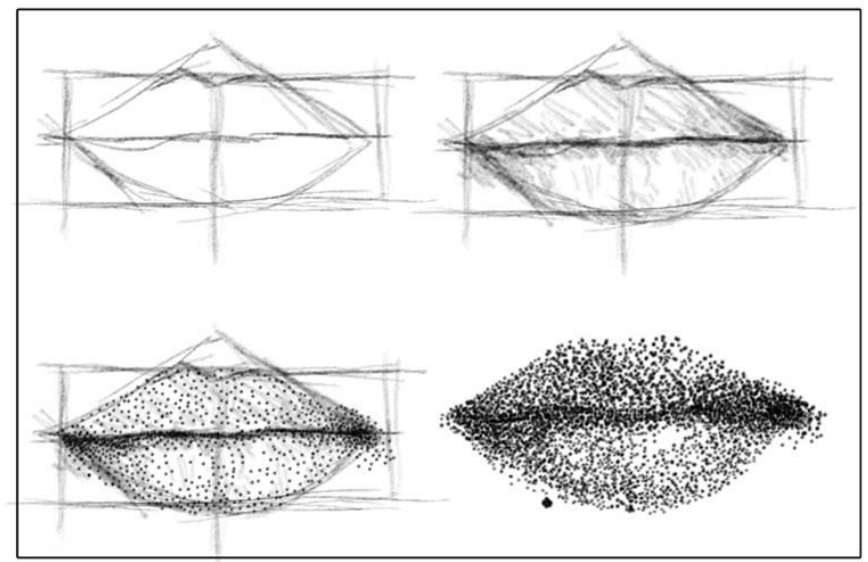

Gbr. 33 Proses Stippling dalam materi membuat Bagian Bibir (Sumber: Dokumentasi Peneliti, 2015/2/5).

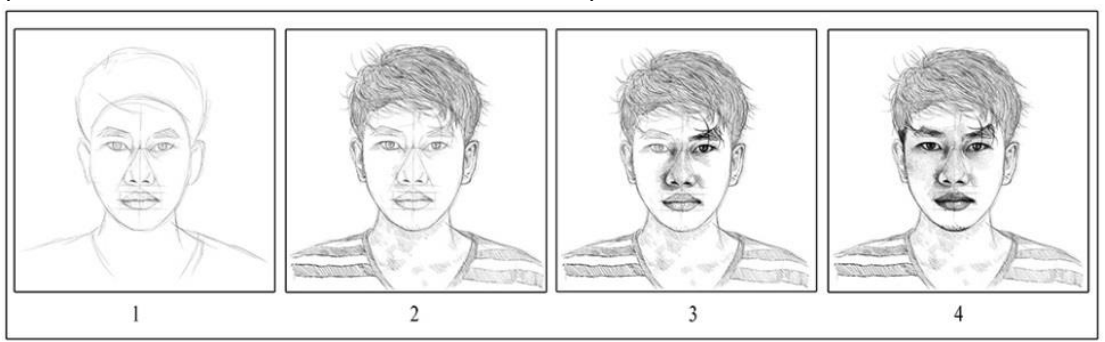

Gbr. 34 Proses Stippling dalam materi membuat Potrait tahap 1-4 (Sumber: Dokumentasi Peneliti, 2015/2/5).

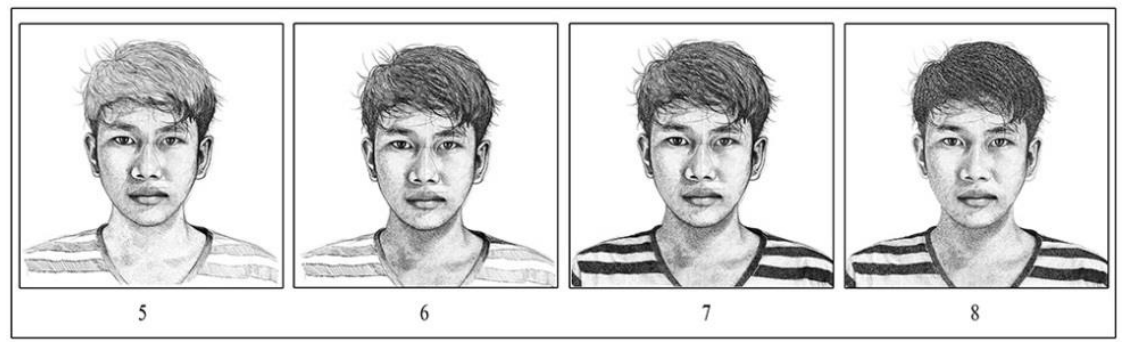

Gbr. 35 Proses Stippling dalam materi membuat Potrait tahap 5-8

(Sumber: Dokumentasi Peneliti, 2015/2/5).

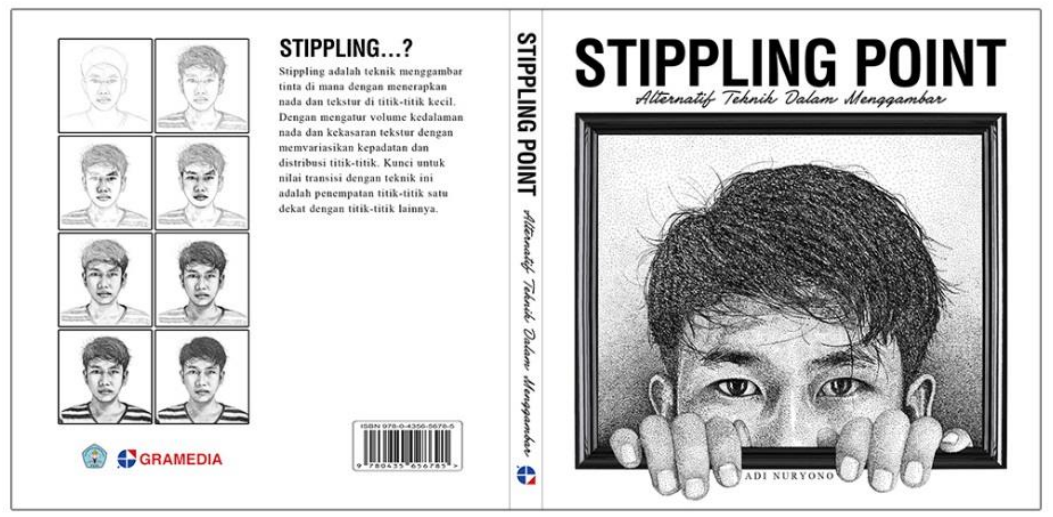

Gbr. 36 Desain Sampul Buku Menggambar Teknik Stippling

(Sumber: Dokumentasi Peneliti, 2015/2/6). 
Dari beberapa uraian mengenai konsep perancangan maka untuk menunjang pembuatan media informasi dibutuhkan media untuk menyampaikan informasi tepat kepada sasaran yang dituju. Adapun uraian media yang akan dibuat sebagai berikut: Pada desain sampul menggunakan gambar dengan teknik stippling. Teknik ini digunakan agar dapat mewakili dan menjadi tanda atau ciri khas. Ilustrasi yang digunakan dalam isi buku menampilkan beberapa tahapan. Berikut ini adalah beberapa layout buku yang sudah dirancang dengan ilustrasi teknik stippling berwarna hitam dan putih.

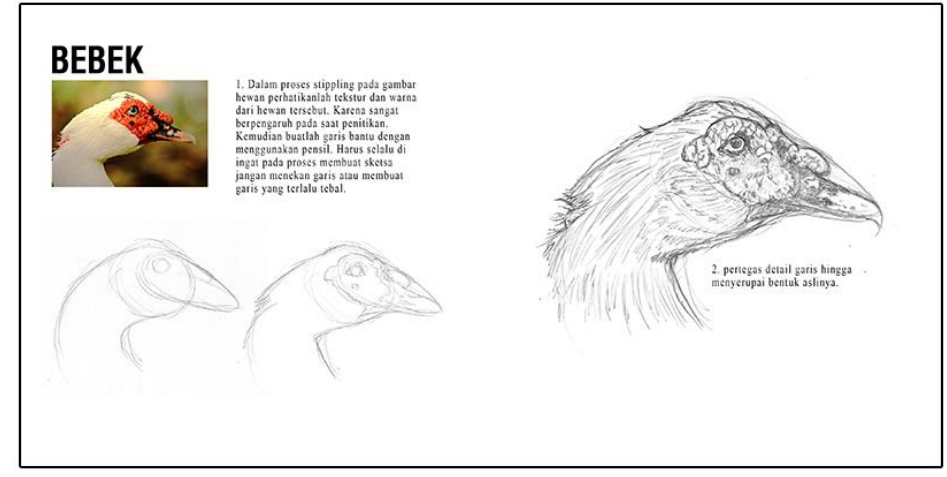

Gbr. 37 Layout isi buku dalam materi Bebek tahap 1 (Sumber: Dokumentasi Peneliti, 2015/1/19).

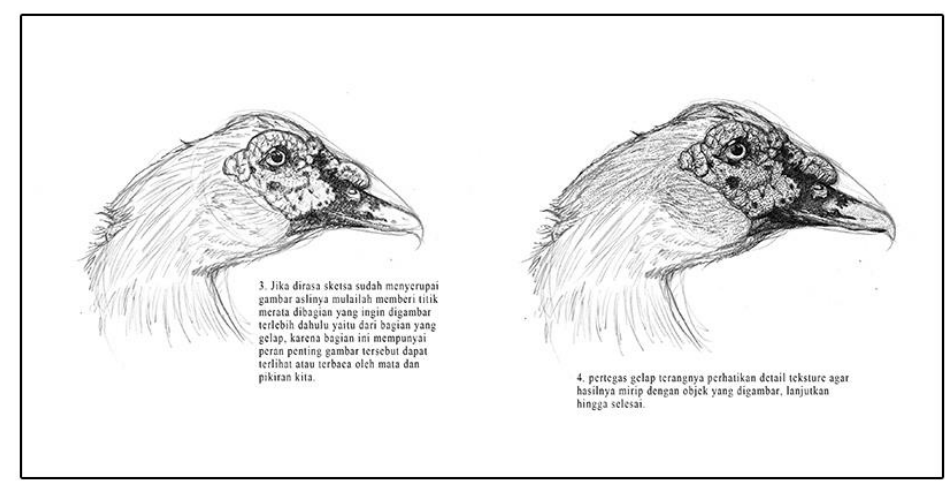

Gbr. 38 Layout isi buku dalam materi Bebek tahap 2 (Sumber: Dokumentasi Peneliti, 2015/1/19).

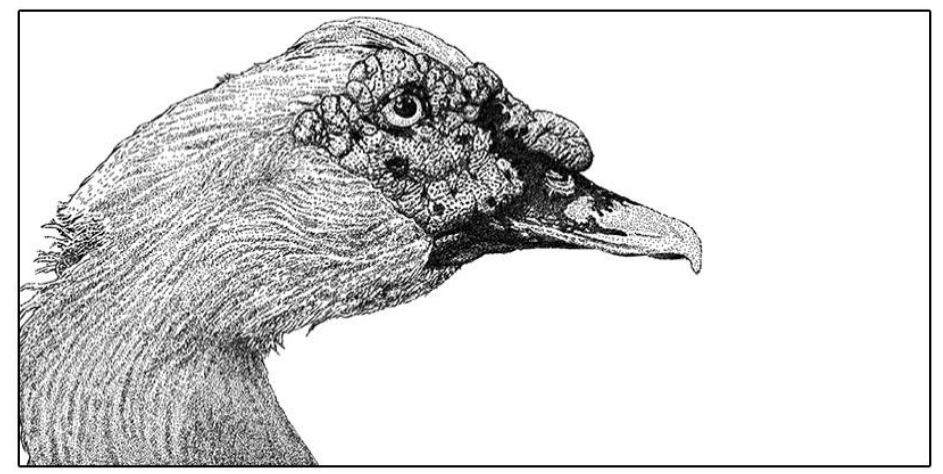

Gbr. 39 Layout isi buku dalam materi Bebek tahap 3

(Sumber: Dokumentasi Peneliti, 2015/1/19). 
Demikian hasil penelitian berbasis perancangan buku teknik stippling dengan warna hitam dan putih. Paparan isi buku lebih diarahkan kepada tahapan praktikal (tutorial), mengingat sasaran khalayak yang dituju adalah para generasi muda yang menyukai minat terhadap melukis dan menggambar.

\section{Simpulan}

Dari beberapa uraian mengenai konsep perancangan hingga hasil perancangan. maka untuk menunjang pembuatan media informasi dibutuhkan media untuk menyampaikan informasi tepat kepada sasaran yang dituju. Terlebih buku tentang teknik stippling sebagai salah satu dari sebagian teknik yang masih jarang didengar, terkait belum adanya buku yang membahas tentang teknik stippling. Buku teknik stippling ini diharapkan dapat memberi gambaran dalam proses membuat gambar stippling, contoh karya diuraikan agar dapat menarik minat masyarakat. Dengan adanya buku teknik stippling ini, diharapkan mampu menjadi bahan acuan dalam melihat karya seni alternatif selain grafis foto, melainkan dengan gambar atau ilustrasi. Kegiatan memperbanyak publikasi tutorial gaya ilustrasi perlu dilakukan penelitian lebih lanjut. Agar teknik stippling ini dapat terus diperkenalkan, tentu dibutuhkan suatu media promosi guna memperkenalkan kepada masyarakat luas. karena secara tidak langsung teknik ini telah menjadi salah satu teknik alternate yang bagus dan masih jarang digunakan karna prosesnya menggunakan waktu yang cukup panjang, dengan ketelitian, serta butuh kesabaran yang besar.

\section{Daftar Pustaka}

Angiel, Cindy. Stippling with Layer - Three Style Tutorial" 03/ Stippling Tutorial. 2012, www.rainbowelephant.com/wp-content/.../2012/03/StipplingTutorial.pdf.

Deussen, Oliver, et al. "Floating Points: A Method for Computing Stipple Drawings." Computer Graphics Forum, vol. 19, no. 3, Wiley Online Library, 2000, pp. 41-50.

Hagijanto, Andrian D. "Metode Dramatisasi Ilustrasi Pada Iklan Sebagai Wacana Budaya Kontemporer." Nirmana, vol. 4, no. 1, 2004.

Hartanto, Deddi Duto. "Penggunaan Ilustrasi Sebagai Daya Tarik Pada Iklan Media Cetak." Nirmana, vol. 3, no. 1, 2004.

Jafar, Aljuk. "Penciptaan Buku Ilustrasi Permainan Tradisional Sebagai Upaya Pelestarian Warisan Budaya Lokal." Jurnal Art Nouveau, vol. 3, no. 1, 2014, pp. 65-73.

Kusmiati, Artini, et al. "Teori Dasar Desain Komunikasi Visual.” Jakarta: Djambatan, 1999.

Natadjaja, Listia. "Pengaruh Komunikasi Visual Antar Budaya Terhadap Pemasaran Produk Pada Pasar Ekspor Ditinjau Dari Warna Dan Ilustrasi Desain Kemasan." Nirmana, vol. 4, no. 2, 2004. 
176 Merancang Buku Stippling dengan Gaya llustrasi Titik Hitam dan Putih Adi Nuryono dan Azhari Amri

Ratna, Nyoman Kutha. Metodologi Penelitian Kajian Budaya Dan IImu Sosial Humaniora Pada Umumnya. Pustaka Pelajar, 2010.

Witabora, Joneta. "Peran Dan Perkembangan Ilustrasi." Humaniora, vol. 3, no. 2, 2012, pp. 65967. 